\title{
A Pragmatic Study of a Political Discourse from the Perspective of the Linguistic Adaptation Theory
}

\author{
Badriah Khalid Al-Gublan ${ }^{1}$ \\ ${ }^{1}$ Princess Nora Bint Abdulrahman University, Riyadh, Saudi Arabia \\ Correspondence: Badriah Khalid Al-Gublan, Associate Professor, Applied Linguistics, English Language and \\ Literature Department, College of Arts, Princess Nora Bint Abdulrahman University, Riyadh, Saudi Arabia. \\ E-mail: Bkh-g@hotmail.com
}

Received: December 16, 2014 Accepted: February 4, 2015 Online Published: March 29, 2015

doi:10.5539/ijel.v5n2p151

URL: http://dx.doi.org/10.5539/ijel.v5n2p151

\begin{abstract}
The emergence of the field of political marketing has highlighted the prominence of communication towards shaping the candidates' image and building long-term relationships with voters. The linguistic characteristics of the political speech presented by candidates allow them to communicate to voters the superiority of his or her attributes over those of opponents (Kaid, 1999). Political campaigns are dynamic struggles between candidates to define the informational context for voters. Early researches (Kaid, 1981, 1986) suggested that political advertising has cognitive and behavioral effects on voters. It communicates the brand promise of a candidate blending functional and emotional benefits that voters gain from their relationships with a candidate.

This study, based on Jef Verschueren's (1999) Linguistic Adaptation Theory (LAT), proposes a pragmatic model for the analysis of a political election discourse. In this pragmatic model, it is shown that in such a discourse the process of adaptation to variables of the physical, social, and mental world is used. Such a process can be understood as the outcome of politicians' choice making, dynamic negotiation and linguistic adaptation. The interpretation of a political discourse, on the other hand, can be better achieved by tracing the specific ways of meaning generation from the four focal points of context, structure, dynamics, and salience.
\end{abstract}

Keywords: political discourse, power, ideology, Linguistic Adaptation Theory, dynamics of adaptability, Salience of adaptability

\section{Introduction}

Politics is a struggle for power in order to put certain political, economic and social ideas into practice. In this process, language plays a crucial role. A political action is prepared, accompanied, influenced and played by language. This research analyzes the discourse of the electional speech given by the Mauritanians candidate, Ahmed Dadeh, in his presidential election campaign in 2009.

\section{Review of the Related Literature}

In a study, Wang (2010) using two speech samples of Obama, victory speech, 2008, and inaugural address on January 20, 2009, summarizes features of his speeches. Horvath (2009) examines the persuasive strategies of Obama's public speaking as well as the covert ideology of the enshrined in his inaugural address. Moore and Hendry (1982) describe 'power' as the force in society that gets things done. So the more access to public discourse, genres, contexts, discourse properties, and talk properties, and the more 'power'ful social groups and institutions are. Studying 'power' may identifies who controls what and for whose benefits. Fairclough (1995) defines 'power' not only as asymmetries that exist between individuals participating in the same discursive event but also in terms of how people have different capacities to control texts and thus discourses are produced, distributed and consumed. According to Baker and Ellece (2011), language is viewed as a social practice and is interested in the ways that ideologies and 'power' relations are expressed through language. According to Van Dijk (1985), when speakers and writers are able to influence the mental models, knowledge, attitudes and eventually even the ideologies of recipients may indirectly control their future action. That is, mentally mediated control of the actions of others is the ultimate form of 'power', especially when the audience is hardly aware of such control, as is the case in manipulation. Most forms of discursive and communicative access, such as control of setting, interaction, topic or style will be geared toward mind controlling of participants, recipients or the 
audience at large, in such a way that the resulting mental changes are those preferred by those in 'power' and generally in their interest. According to Baker and Ellece (2011), Norman Fairclough views ideologies as constructions of reality which are built into various dimensions of the forms/meanings of discursive practices, and which contribute to the production, reproduction or transformation of relations of domination. According to Van Dijk (1995), ideologies are usually expressed and reproduced in discourse, verbal and non-verbal communication and other forms of interaction. They are often embedded in organization and institutional contexts. However, among the many forms of reproduction and interaction, discourse is the most suitable and preferred site through which ideologies are formulated and communicated explicitly and verbally. Thus, ideologies may be expressed and communicated in text and talk variably and indirectly and discourses are used as a suitable and preferential means to construct new ideologies and confirm already present ones.

\section{The Objective of the Study}

This research aims at discussing the realisation of 'identity' by means of language use in a political discourse which is mainly grounded in Jef Verschueren' s LAT. For this aim, the discursive strategies of the political advertising messages of the Mauritania candidate, Ahmed Dadeh, presidential election discourse in 2009will be examined within the context of his ideological, cultural and language background.

\section{The Significance of the Study}

This study attempts to approach the presidential election discourse through the prespective of Jef Verschueren's LAT which has not been tackled in the previous studies. Verschueren' theory explains language use from cognitive, social and culture aspects and assumes that language use is a continuous making of linguistic choices with different degrees of salience for the purpose of adaptation. A political language is a process of verbal communication. In language using, it has a high initiative to choose the pragmatic strategies, and high degrees of consciousness participation. It adapts the communicative context dynamically considering all the ingredients of the communicative context. At the same time, the choices of a political language have high degrees of political consciousness and standpoint.

\section{The Model of the Study}

\subsection{Jef Verschueren's LAT}

The 'power' of LAT lies in that it offers an explanatory and coherent theoretical framework for the research of language use. The essence of this theory may be summarized as follows:

Verschueren proposes that "using language must consist of the continuous making of linguistic choices, consciously or unconsciously, for language-internal (i.e., structural) and/or language-external reasons" (Verschueren, 1999, pp. 55-56). It is further explained that choices are made in the aspects of communicative strategies as well as linguistic forms. In fact, the language user is under an obligation to make choices whenever he/she enters the dynamic process of communication. Furthermore, choices are made not only by language politicians but also by interpreters, and both types of choice making are of equal importance for the success of communication. It deserves our attention, however, that all choices are made with varying degrees of consciousness.

The view that language use is a process of choice making is based upon the three properties of language, namely, variability, negotiability and adaptability. Variability is the property of language which defines the range of possibilities from which choices can be made; negotiability is the property of language responsible for the fact that choices are not made mechanically or according to strict rules or fixed form-function relationships, but rather on the basis of highly flexible principles and strategies; adaptability is the property of language which enables human beings to make negotiable linguistic choices from a variable range of possibilities in such a way as to approach points of satisfaction for communicative needs (Verschueren, 1999, pp. 59-61). It should be emphasized that the three notions are not separate topics of investigation but interrelated properties of the overall research object for the pragmatic perspective. The former two are necessary to the adequate understanding of the third property, which is a higher-order notion in the hierarchical ranking.

Using the higher-order notion of adaptability as the starting point of language study, we should take the four focal points into consideration, including contextual correlates of adaptability, structural objects of adaptability, the dynamics of adaptability, and the salience of adaptation process. The contextual correlates of adaptability can be depicted as Figure 1 (Verschueren, 1999, p. 76): 


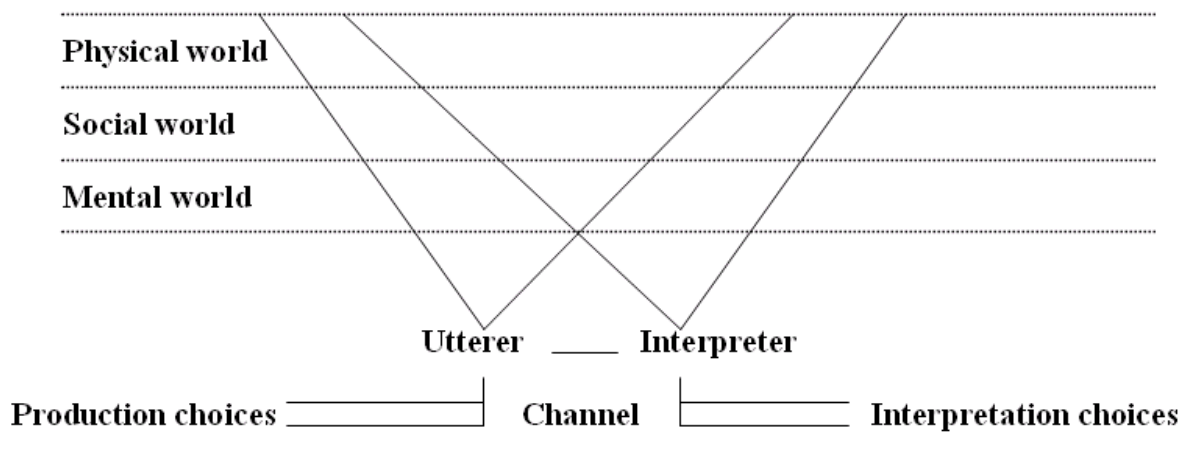

(Linguistic context)

Figure 1. Contextual correlates of adaptability

Figure 1 indicates that all the linguistic and extra-linguistic factors related to a language phenomenon are within the visual field of "context". Specifically, we should take all components of the communicative context into account in order to examine their interadaptive relations with linguistic structures. Ingredients of communicative contexts include language users (utterer and interpreter), mental world, social world, and physical world. Besides the communicative contexts, linguistic channel and linguistic context also belong to the contextual correlates of adaptability. The structural objects of adaptability include the structures at various layers of linguistic organization and the principles of "structuring". The dynamics of adaptability involves the dynamic generation of meaning in communication, or the ways in which communication principles and strategies are used in the making and negotiating of choices of production and interpretation. The salience of the adaptation process accounts for the fact that not all linguistic choices are made with equal degree of consciousness; instead, some are highly motivated while others are virtually automatic with the functioning of medium of adaptability mind in society. The above four angles of investigation are not separate research topics but focal points in one coherent pragmatic approach to language use. None of them can either be ignored or underestimated because of an adequate pragmatic perspective. Their relations can be illustrated in Figure 2 (Verschueren, 1999, p. 67): they are necessary and inter-related ingredients.

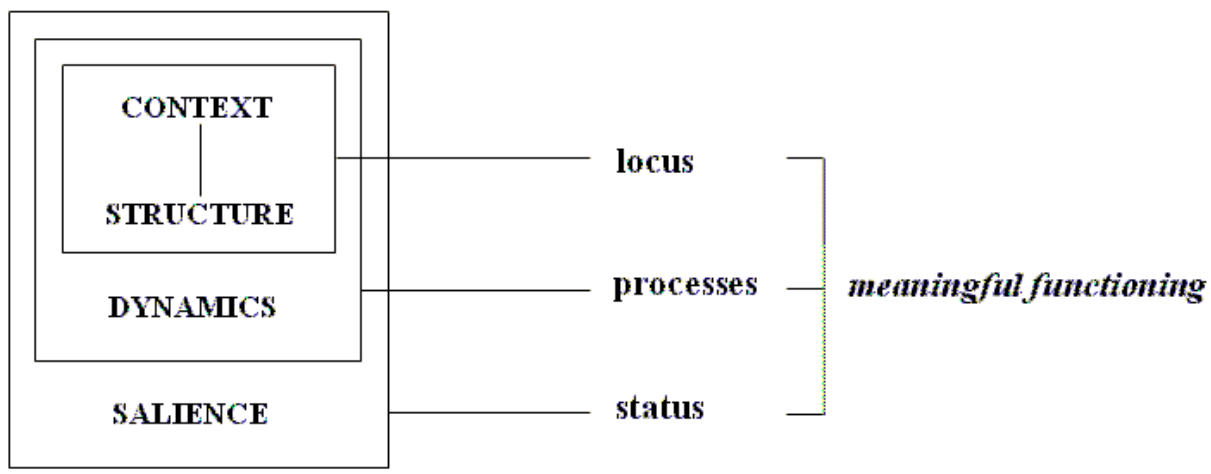

Figure 2. The structure of a pragmatic theory

It is considered that context and structure are the locus or 'place' where the dynamic processes of adaptation take place with different degrees (or status) of salience. In other words, the use of language is a dynamic process of mutual adaptation between linguistic structure and context at different levels of salience. The idea conveyed by Figure 2 not only sketches out the general picture of the LAT but also lays a sound theoretical foundation for the present study. So far as the research of a political discourse is concerned, the present study suggests that the continuous making of linguistic choices from the repertoire of forms and strategies to approach different pragmatic functions, which has taken a shape within the scope of Verschueren's LAT. Moreover, since 
variability, negotiability, and adaptability are universal properties of language, a political discourse makes no exception. The producing and consuming of a political discourse are no doubt results of the dynamic adaptation between contextual and structural correlates of adaptability. All the above considerations can be accounted for from the four focal points proposed by the LAT. Therefore, they are chosen as the theoretical foundation of this study.

\section{The Research Questions}

This study addresses the following research questions:

1) What roles do culture and 'power' play upon the 'identity' of a candidate as evident in his/her linguistic choices in his/her political discourse?

2) How does a candidate employ hislinguistic repertoire offered to construct a recognizable 'identity' in his political discourse?

\section{The Research Hypotheses}

This study is based on the following research hypotheses:

1) Culture and 'power' play an important role upon the 'identity' of candidates as evident in his linguistic choice in his political discourse.

2) A variety of strategies are used by a political Arab candidate employing hislinguistic repertoire to construct a recognizable 'identity' in his political discourse.

\section{Methodology}

\subsection{Data Collection}

The collected data of this study is the speech of the Muretanian candidate, Ahmed Dadah during the presidential election period in 2009 .

\subsection{Data Analysis}

The data of the study is analyzed, as shown in Table 1, according to Jef Verschueren's LAT focusing on specific lexis and sentence structures which operate as indicator to 'identity' and 'power'.

Table 1. Data analysis

\begin{tabular}{lll}
\hline A Language user & Physical world & Social world \\
\hline \multirow{2}{*}{ the Mauritanians candidate Ahmed Dadeh } & Mauritania & \multicolumn{2}{c}{ Presidential election } \\
\cline { 2 - 3 } & \multicolumn{2}{c}{ Passive } \\
\hline
\end{tabular}

Table 2. Data analysis

\begin{tabular}{|c|c|c|c|}
\hline \multirow{2}{*}{\multicolumn{2}{|c|}{ Linguistic discourse }} & & \multirow{3}{*}{$\begin{array}{l}\text { Mental World } \\
\text { Salience of adaptability } \\
\text { Status }\end{array}$} \\
\hline & & \multirow{2}{*}{$\begin{array}{l}\text { dynamics of adaptability } \\
\text { Processes }\end{array}$} & \\
\hline \multirow[t]{2}{*}{ No. } & locus (place) & & \\
\hline & Pasive & \multicolumn{2}{|l|}{ Active } \\
\hline 1 & In the name of God the Gracious the Merciful. & $\star$ The use of religious statements & $\begin{array}{l}\text { He is highly motivated to start his } \\
\text { speech by mentioning } \\
\text { the name of God with which any } \\
\text { speech or work is introduced. }\end{array}$ \\
\hline 2 & $\begin{array}{l}\text { و الصلاة و السلام على أنشرف الأنياء و المرسلين. } \\
\text { peace and blessings be upon His prophets and } \\
\text { messengers. }\end{array}$ & The use of religious statements & $\begin{array}{l}\text { He is highly motivated to pray for } \\
\text { prophet Mohamed and his } \\
\text { companions as kinds of the } \\
\text { worship. }\end{array}$ \\
\hline 3 & 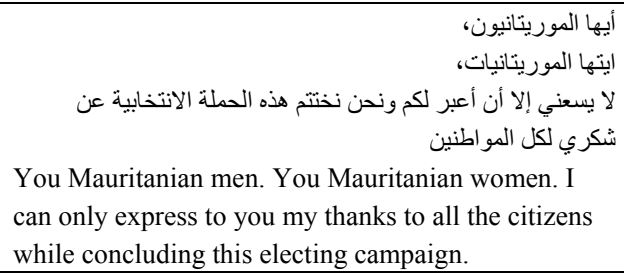 & * Thanking his voters & $\begin{array}{l}\text { He is highly motivated to address } \\
\text { his voters directly to express his } \\
\text { thanks and deep gratitude and to } \\
\text { show his compassionate. }\end{array}$ \\
\hline 4 & 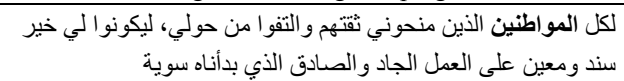 & $\begin{array}{l}\text { The use of striking phrases and short } \\
\text { sentences: }\end{array}$ & $\begin{array}{l}\text { He is highly motivated to address } \\
\text { directly his thanks and deep }\end{array}$ \\
\hline
\end{tabular}




\begin{tabular}{|c|c|c|c|}
\hline & $\begin{array}{l}\text { To all the citizenswho gave metheir trust and rallied } \\
\text { around me to be my best support and help for the } \\
\text { hard and sincere work which we have started } \\
\text { together. }\end{array}$ & 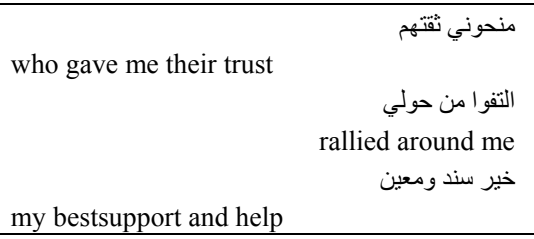 & $\begin{array}{l}\text { gratitude to his voters who have } \\
\text { supported him by providing him } \\
\text { with their trust and devotedness. }\end{array}$ \\
\hline 5 & 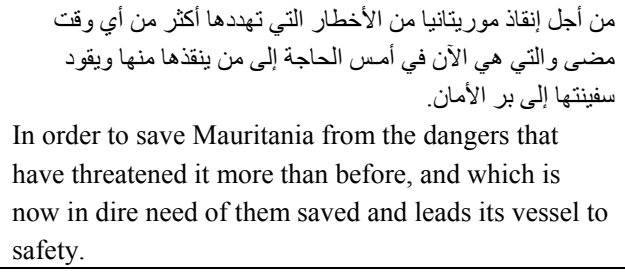 & $\begin{array}{l}* \text { Use of three tenses simultaneously. } \\
\text { Expectation for future } \\
* \text { Reference to the past (history) } \\
\text { Reference to the present condition }\end{array}$ & $\begin{array}{l}\text { He intends to motivate his voters } \\
\text { to support and elect him to be the } \\
\text { president of Mauritania by } \\
\text { mentioning the fact of the } \\
\text { existence of danger which has } \\
\text { threatened and the necessity of } \\
\text { protecting it. }\end{array}$ \\
\hline 6 & 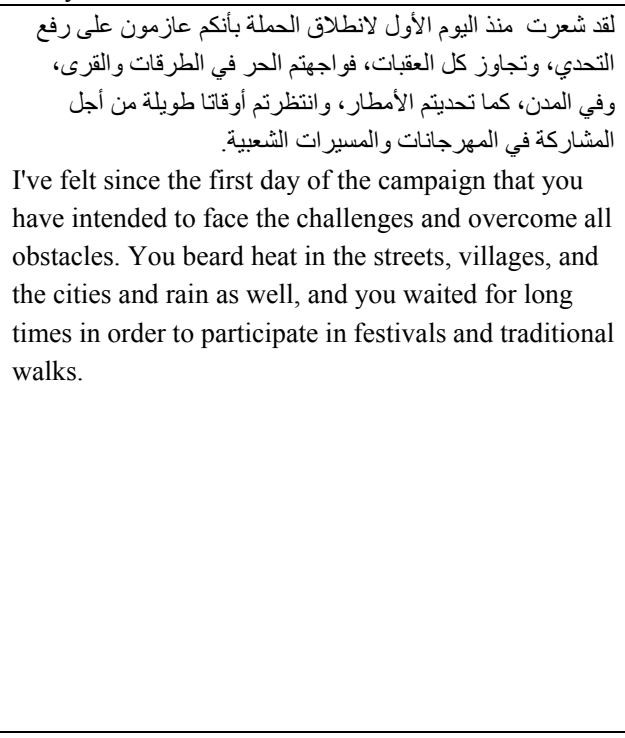 & 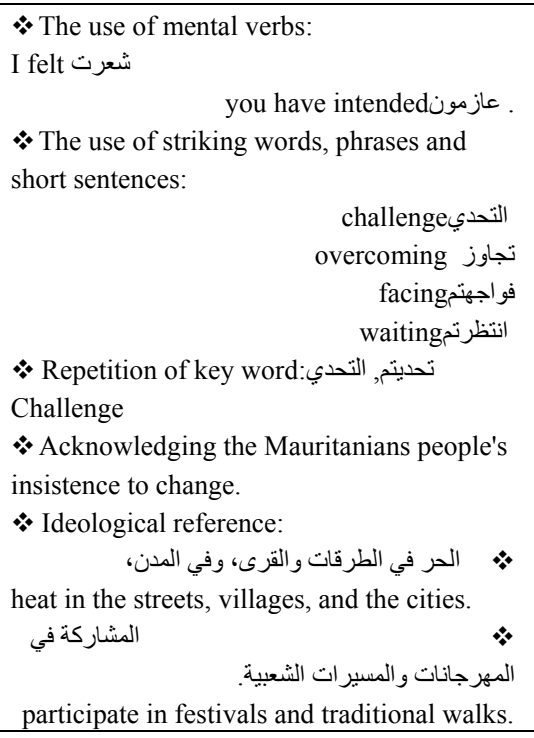 & $\begin{array}{l}\text { He intends to show his trust, } \\
\text { devotedness, and respect to the } \\
\text { Mauritanians by using the mental } \\
\text { verbs expressing their insistence } \\
\text { to overcome all challenges and } \\
\text { obstacles. }\end{array}$ \\
\hline 7 & 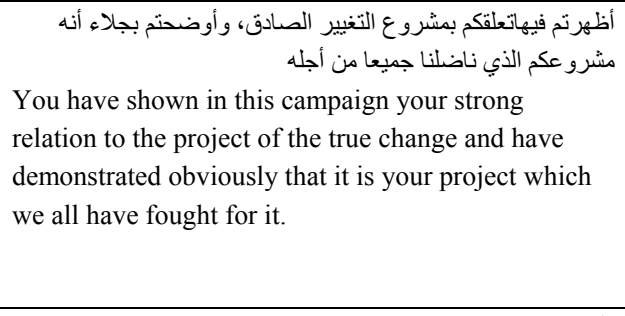 & 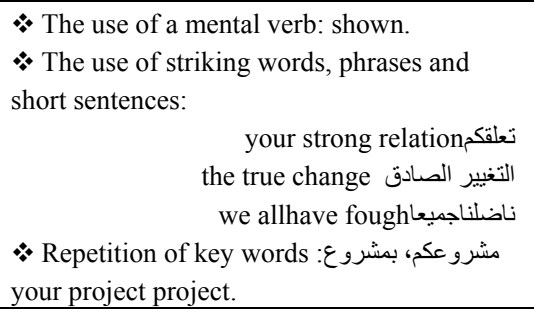 & $\begin{array}{l}\text { He appreciates the positive } \\
\text { attitude of the Mauritanians } \\
\text { towards the change and how they } \\
\text { fight and struggle for it. }\end{array}$ \\
\hline 8 & 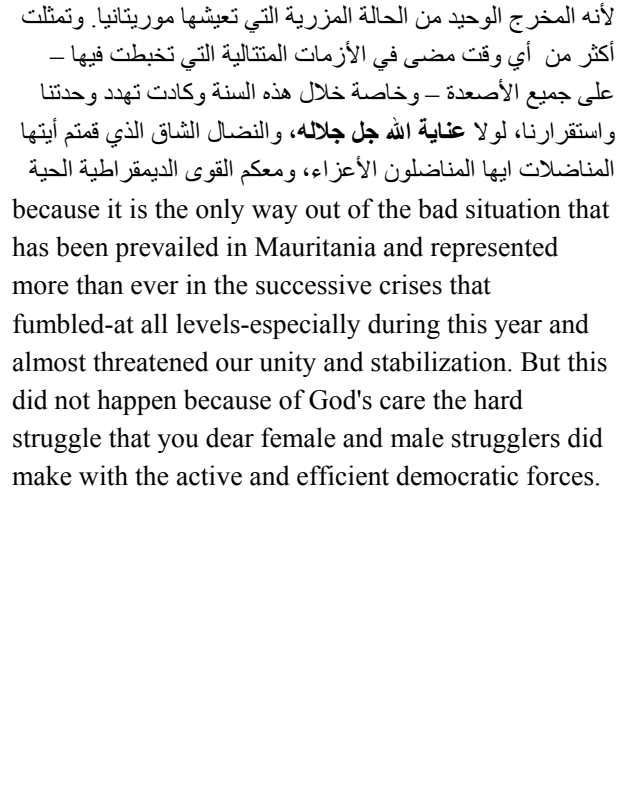 & 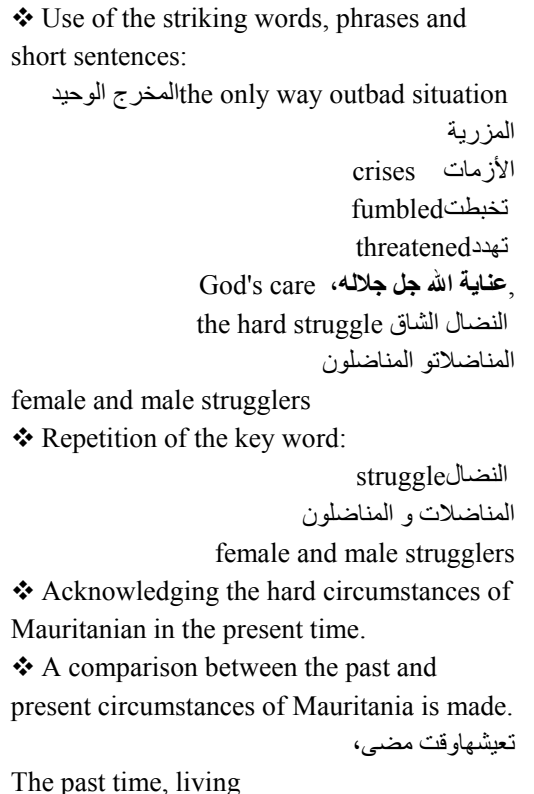 & $\begin{array}{l}\text { He intends to emphasize the } \\
\text { danger of the bad political } \\
\text { circumstances of Mauritania to } \\
\text { their unity and stabilization and } \\
\text { the necessity of struggle for } \\
\text { change. }\end{array}$ \\
\hline
\end{tabular}


* The use of religious expression:

عناية الله جل جلالهd's care

* Enumerating the factors behind the ability of the Mauritanians to overcome the threats and challenges they have been facing.

9 حتى فرضنا اتفاق دكار الذي قسم السلطة لأول مرة بينالقوى السياسية

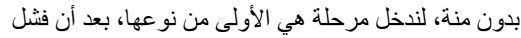

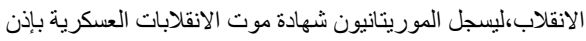
اله.

We imposed the Dakar agreement which has divided the authority for the first time into political forces without thankfulness to start the stage which is the firstof its kind after the failure of the revolution in which the Mauritanians have registered the certificate of the death of the military revolutions, God's willing.

\section{* Use of striking words, phrase and short} sentences:

\section{We imposed فرضنا}

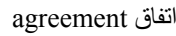
فسم السلطة without thankfulness بدون المنة

* The use of juxtaposition :

فرضنا We imposed اتفاقagreement

* The use of images by using personification:

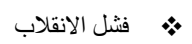

thefailure of the revolution

$$
\text { • موت الانقلابات العسكرية }
$$

the death of the military revolutions

* The use of religious statements.

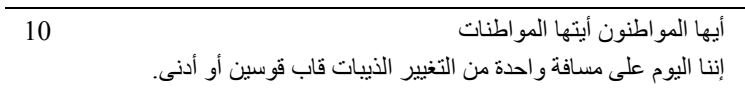

You male and female citizens. Today we are at the same distance from the change that is about to be done.

(s)

\section{sentences:}

* Ideological reference

the same distance مسافة واحدة

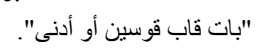

\begin{tabular}{|c|c|}
\hline \multirow[t]{2}{*}{11} & 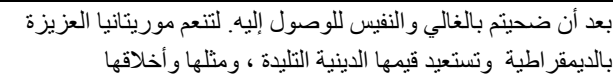 \\
\hline & $\begin{array}{l}\text { After you had sacrificed the valuable and unique } \\
\text { things that you owned to achieve it. Mauritania will } \\
\text { enjoy democracy and regain its ancient traditional } \\
\text { religious values, and its ideals and morals. }\end{array}$ \\
\hline
\end{tabular}

that is about to be done

its ancienttraditional

* Use of striking words, phrases and short sentences:

ضحيتم بالغالي

،unique النفيسsacrificed the valuable things تنعم enjoy قيمها الدينية التليدة

religious values مثلها وأخلاقها

its ideals and morals.

* Repetition of key words:

$$
\text { * Ideological reference: قالديمقر اطية }
$$

its ancienttraditional

religious values

its ideals and morals

- The use of juxtaposition:

$$
\text { مثلها وأخلاقها }
$$

ضحينتمou sacrificed تنعمenjoy

regain تستعيد

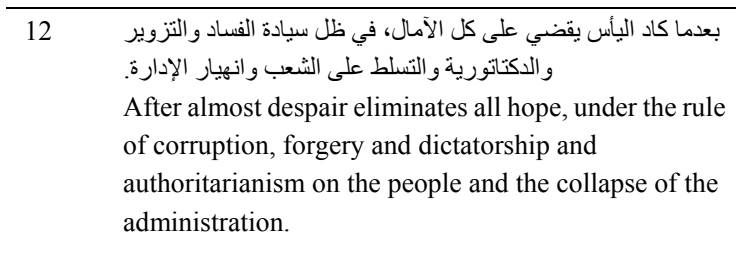

اليأس، despair

الآمال، اليان،

الفساد، الأ، corruption

forgery التزوير،

الدكتاتورية التونية و التسلط، dictatorship
He intends to motivate his voters to believe more in the necessity of changing their political situation. He confirms the fact that the solutions of the problems lie in God's willingness and the potential of the Mauritanians to change and guide the country to a good situation.
He is highly motivated to show his voters that they and him are in a close relationship. They are all the citizens of Mauritania who struggle for change and and improvement.
He admires the sacrifice of his voters for changing the bad and hard circumstances of Mauritania to the democracy of the country based on religion and morals.
He intends to emphasize the fact that Mauritania has suffered a lot from the bad and hard political environment that it has been involved in. 
* Acknowledging the bad and hard

circumstances of Mauritania by enumerating

the characteristics of the current government:

الفساد، corruption

forgery التزوير،

الدكتاتورية الترون

و التسلط، لنsctatorship

collapse انهيارن

و وأمام هذه التحديات يحتاج بلدنا إلى قيادة قوية، توفر لمو اطنيه العيش 13

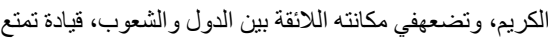

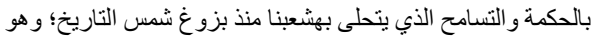

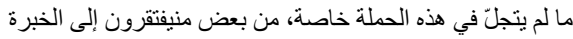

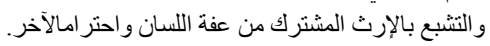

Faced with these challenges, our country needs a strong leadership which provides its citizens a good living, and puts it in its suitable place among nations and peoples. It also needs a leadership which is characterized by wisdom and leniency which the Mauritanians are known since the beginning of their history. This has not been reflected in this particular campaign because of those citizens who are inexperienced and lack the shared heritage of the virtue of tongue and the respect others.

* Use of striking words, phrases and short sentences:

challenges، التحديات

a قيادة قوية،a strong leadership

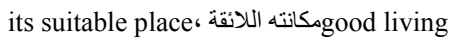
قيادة تمتع بالحكمة و التنسامح

a leadership which is characterized by wisdom and leniency

* The use of juxtaposition:

$$
\text { hope،اليأس، hespair }
$$

* The use of images:

the beginning of their history

$$
\text { بزوغ شمس النتاريخ }
$$

* Acknowledging some of the characteristics of Mauritanian people:

$$
\text { الحكمة ،التسامح }
$$

wisdom and leniency

- Repetition of the key word:

$$
\text { a leadershipaياد }
$$

* Ideological reference for the sake of emphasizing the sense of unity:

$$
\text { والإرثر امالاخر المشترك من عفة اللسان }
$$

the shared heritage of the virtue of tongue and the respect others.

* Enumerating the good characteristics of a good leader which Mauritania needs and which he himself has.

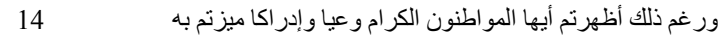

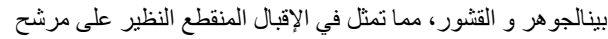

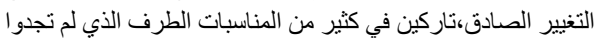

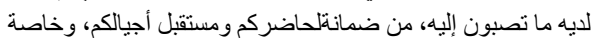

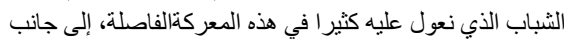

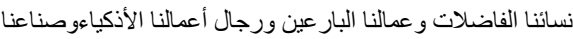

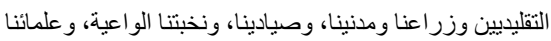

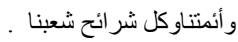

However, dearcitizens, you have showed awareness and consciousness which have made you identify essence from artificialities. This is reflected in your overwhelming turnout of the sincere candidate of the change leaving in many occasions the one with whom you did not find what you have aimed at which is the guarantee of your present life and the future of your youths, especially the youth whom we rely heavily on them in this interval battle, along with our women and our traditional workers, our intelligent businessmen, craftsmen,

farmers, civilized hunters, elitists, scientist, religious people and all types of our people.

\section{* The use of striking words, phrases and} short sentences:

الجوهر essence artificialities القشور التاركين leaving الصادق،

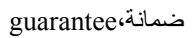
rely on، نعول عليهنة كل شر ائح شعبنا.

* The use of mental verbs:

أظهرتم، Showed identify، ميزنم، تصبو aim at

* The use opposing images:

$$
\begin{aligned}
& \text { essence } \\
& \text { مرشح التغيير الصادق\#\# الطرف الذي لم تجدو الديه ما } \\
& \text { تصبون إليه }
\end{aligned}
$$

the sincere candidate of change\# the one with whom youdid not find what you have aimed at.

* The use of two opposing attitudes of the Mauritanians:
He intends to persuade his voters through reasoning about the necessity of changing the current government which is so weak and failed and has made the country suffer such political and social unstableness. He asks them to keep on supporting him to be elected the future president.
He thinks very highly of himself. He intends to show his voters that he is highly qualified to be a 'power'ful successful leader by distinguishing between him and those candidates who do not have the potential to satisfy the Mauritanian people referring to his future plan activating the important role of all kinds of Mauritanian people for the sake of strengthening the notion of unity and brotherly love. 
those citizens who are inexperienced and lack the shared heritage of the virtue of tongue and the respect of others\#those who have shown awareness and consciousness which have made you identify essence from artificialities.

* He introduces himself as the best candidate who deserves to be elected the president of Mauritania.

the sincere candidate of change

* Persuasion through personality and stance.

* Enumerating all kinds of Mauritanian people and referring to them as being collective.
و أدعوكم جميعا في يوم الثامن عشر من يوليو إلى أن تتوجهو اجميعا 15

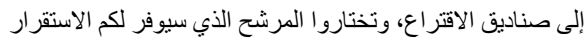

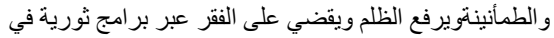
جو هر ها، تعنمد على الدر اسة و التخطيطو الصر امة فئس في التنفيذ، تمول

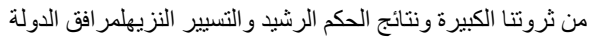

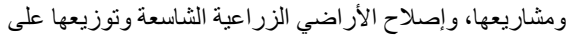

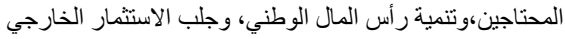
وتوزيع الثروة في مشروع تنميةشاملة ينعم الجميع بنتائجه.

I invite you all on the eighteenth of July to go to the voting and choose the candidate who will provide you with stability and peace of mind and get rid of the injustice and eliminate poverty through programs. These programs are essentially revolutionary based on study, planning and rigor in achievement and funded from our big wealth. They are the results of good governance and management of the facilities and agricultural lands and distributing them to the needy, the development of the national capital, and bring in foreign investment the distribution of wealth in the comprehensive developmental project from which everyone benefits.

ومثل هذا النهج هو الذي يضمن سيادة القانون لاقانون القوة، وإعادة 16

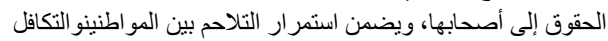

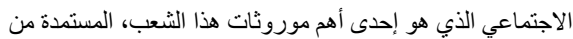
الإسلامالحنيف وسنة الرسول ونهج صحابته, في ظل دولة المؤس الستات. Such a policy ensures that the occupyin law is not the law of force, and regain the rights to their owners.It ensures the continuation of relationship among citizens and the social solidarity, which is one of the most important heritages of this people which is derived from the Islamic religion and the Sunnah of the Prophet and his companions's approach, and under the state of institutions. projects of the country, the reform of the vast

* Definition of the key word المرشح

* Expaining the details of his evolutionary program.

* Repetition of key words:

$$
\begin{aligned}
& \text { وأدعوكم invite you } \\
& \text { جميعاديا } \\
& \text { المرشح a candidate }
\end{aligned}
$$

* Ideological reference for the sake of emphasizing the sense of unity: تتوجهو اجميعا إلى صناديق الاقتر اع، وتختاروا المرشح you all ... go to the voting and choose the candidate.

* Offerring an invitation to all kinds of Mauritanian people.
He intends to clarify his future government objectives indirectly for the sake of motivating his voters to elect him the president of Mauritania. plan in order to refer to his

\section{* Preposition of the key word: القانون lawwhich is the theme of the discourse. * Repetition of the key word: القانون policy. * Acknowledging the meaning of the policy of his government. * Ideological reference for the sake of emphasizing the sense of unity:

$$
\text { التلاحم بينالمو اطنين }
$$ \\ the continuation of relationship among \\ He is highly motivated to make his voters believe in him as being having the potential to be the president of Mauritania by clarifying his future plan referring to his government objectives indirectly and by evoking their emotions through the reference to their heritage and religion.} citizens

the social solidarity,

موروثات هذا الشعب، heritages of this people

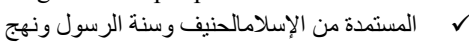

derived from the Islamic religion and the

Sunnah of the Prophet and his companions's approach

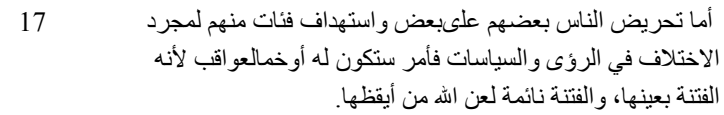

The provocation of people on each other and targeting some of them just because of the difference among

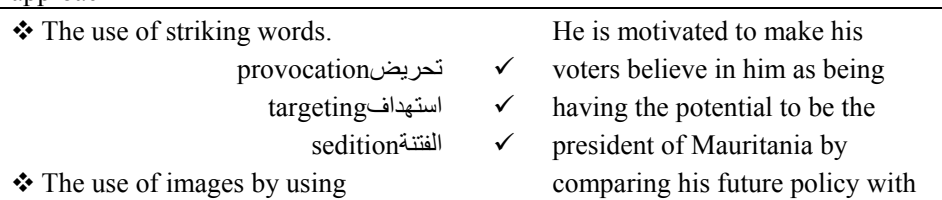


them in visions and policies are issues which will have the gravest consequences which are sedition itself. The sedition is sleeping and God curses who intends to wake it up.

personification:

$$
\text { الفتتة نائمة لعن الله من أيقظها. }
$$

sedition is sleeping and God curses who intends towake it up.

* The use of threat.

$$
\text { أمور سنكون له أوخمالعو اقب }
$$

issues which will have the gravest consequences

$$
\text { الفتنة نائمة لعن الهه من أيقظها. }
$$

The sedition is sleeping and God curses who intends to wake it up.

18 أيهاالمو اطنون

إننا رغم الاختلاف في الرؤى، معنيون جميعابحاضر موريتانيا

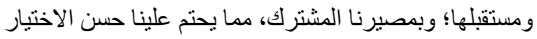

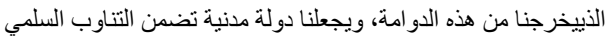
على السلطة.

You male citizens

you female citizens

We, despite the difference in our points of view, are all concerned with the presence and the future of Mauritania; and our common destiny which necessitates us to get a good choice which relieves us from this vortex, and makes us a civil country that guarantees the peaceful rotation of the government.

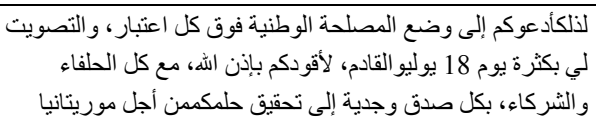

الديمقر اطية.

so I invite you to put the national advatage above all, and vote increasinglyfor me on July 18 to guide you, God 's willingness, with all allies and partners in all sincerity and seriousness to achieve your dream of Mauritania for democracy.
* The use of striking words and phrases to indicate unity: الدوامة vortex

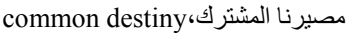
a good choice، حسن الاختيار

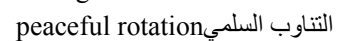
concerned معنيون we have to يحتم علينا

* Repetition of the key word: المو اطنون المو اطنات male and female citizens

* The use of juxtaposition: الاختلاف difference المشترك common الدوامة الافلاف \#ortex دولة مدنية تضمن التناوب السلمي على السلطة

a civil country that guarantees the peaceful rotation of the government.

* The use of striking words, phrases and
short sentences:

advatagenational

صدق وجدية sincerity and seriousness

* Repetition of the key word:

أدعوكم I invite you

* The use of religious statements:

* Ideological reference: بإذن الهـ God 's willingness

voteincreasingly

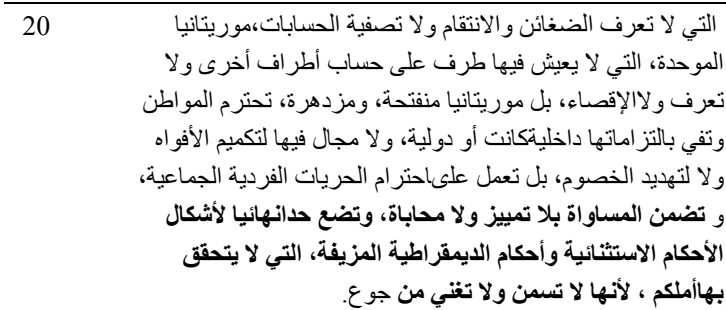

for Mauritania which does not know grudges and, the unitied Mauritania, where one does not live at the expense of the other, but Mauritania which is open, prosperous. It respects the citizen and meets the internal and international commitments. There is no way of closing mouths nor threatening opponents, butit works in respecting individual and public freedom, and ensures equality without discrimination or favoritism.It puts an end to the forms of special provisions and the provisions of fake democracy, by which you cannot achieve your hope, because it is not beneficient.

\section{* Repetition of the key words: الايمقر اطية democracy

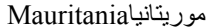

* The use of religious statements: لا تسمن ولا نغني من جوع.

It is not beneficient.

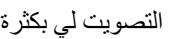

C.

the policy of the current government.

He made a distinction between the present government in which the Mauritanian people suffer of hard political and social circumstances and his future policy which calls for democracy and peace.
He is motivated to make his voters believe in him as be having the potential to be the president of Mauritania by clarifying his future plan referring to his government objectives directly. 
21 أيها المواطنونالأعز اء؛

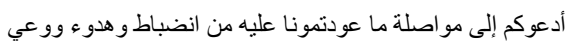

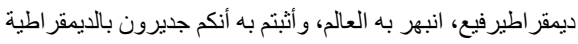

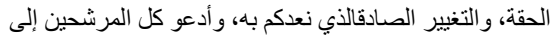

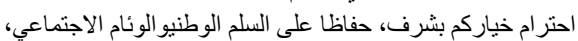

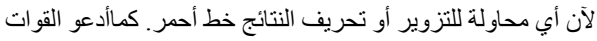

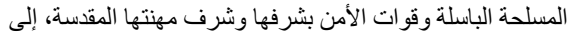

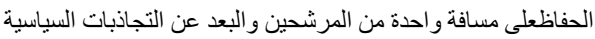
واحترام خيار الناخبين،لأن ذلك خط أحمر.

Dear citizens;

I invite you to to continue what we have used to have fromyou; that is discipline, calmness and high democratic awareness by which the world has been fascinated, and you have proved that you have deserved the true democracy and the true change that we have promise to provide you with. I call on all the candidates to respect your choice honorably in order to preserve the national peace and the social harmony because any attempt for fraud or misrepresentation of the results is a red line. I call on the valiant armed forces and the profession of security forces to maintain the same distance from the candidates and keep away from the political disputes and respect the voters's choice, because it is a red line.

* The use of striking words, phrases andshort sentences:

High democratic awareness وعي ديمقر اطي رفيع

the world has been fascinated انبهر به العالمالحفة

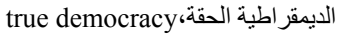
true change التغيير الصنادية

national peace and because any السلم الوطنير الماني attempt for fraud or misrepresentation of the results

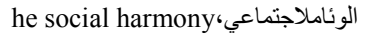
fraud or التزوير او تحريف النتائي، misrepresentation of the results خط أحمر a red line political disputesالتجاذبات السباسية النية احترام خيار الناخبين

respect the voters 's choice

* Repetition of the key words and phrases: الديمقر اطية democracy خط أحمر a red line changethe التغيير

* Ideological reference: أدعو القوات المسلحة الباسلة وقوات الأمن بشرفها وشرف

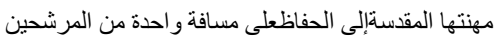
والبعد عن التجاذبات السياسية واحتر ام خيار الناخبين. I call on the valiant armed forces and the profession of security forces to maintain the same distance from the candidates and keep away from the political disputes and respect the voters 's choice, because it is a red line. * The use of threat:

$$
\begin{aligned}
& \text { أدعو القوات المسلحة الباسلة وقو ات الأمن بشرفهاوشرف }
\end{aligned}
$$

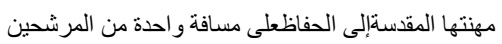

$$
\begin{aligned}
& \text { و البعد عن التجاذبات السياسية واحتر ام خيار الناخبين.لان النيان } \\
& \text { هناك خط احمر. }
\end{aligned}
$$

I call on the valiant armed forces and the profession of security forces to maintain the same distance from the candidates and keep away from the political disputes and respect the voters 's choice, because it is a red line.

22 أيها المو اطنون:

إن الهذف المنشود في متناولكم ؛بالتصويت لي يوم الاقتر اع، فامنحوني

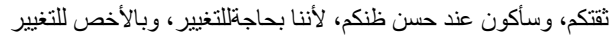

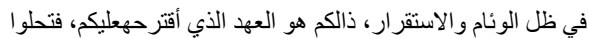
بالإر ادة الكافية لمصلحة أبنائنا ولمستقبل بلدنا.

You citizens:

The intented aim is in your hands; vote for me on the voting day. Give me your trust, and I'll be as you expect me because we need the change in particular the change in the time of harmony and stability, the time which I propose to you. You should have for the benefit of our children and for the future of our country.

"وما توفيقيالا بالله عليه توكلت و إلبه أنيب"

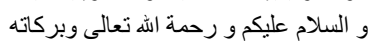

The only compromise I put my trust on is God on Him I rely.

Peace be upon you and Allah's mercy and blessings be upon you.
He is motivated to make his voters believe in him as being having the potential to be the president of Mauritania by comparing his future policy with the policy of the current government.
* Repetition of key words:

التغيير changethe المواطنون citizensthe

* The use of striking words, phrases and short sentences:

الهدف المنشودThe intented aim changethe التغيير ظل الوئام و الاستقرار in the time of harmony and stability

* Persuasion through personality and stance.

* Enumerating the

procedure the Mauritanians should follow in order to achieve their main aim which is the change to good life.

* The use of religious statements.

He is highly motivated to end his speech by praying to God for help him to succeed.
He intends to motivate his voters to believe more in the necessity of changing the political and social situation of Mauritania. He confirms the fact that the only factor which achieves their aims and dreams are believing in him and in their potentiality to change. 


\section{The Results}

Political advertising reflects the uniqueness of an indigenous culture. In communication, a politician's cultural background affects the overall message form.

Variability is meant to cover the entire range of variable options that are assumed to be accessible to language users for them to make choices. This property of language is of crucial importance to the fulfillment of communication. A political discourse possesses a wide range of variations, which makes interdiscursive texts possible and flexible in communication. In the present study, variability refers to the linguistic diversity manifested in interdiscursive texts in terms of element complexity, a political discourse types and application domains.

The existence of political discourse variability, on the one hand, shows the diversity and complexity of interdiscursive texts in linguistic forms and, on the other hand, it accounts for the difficulty in the research of a political discourse.

While making linguistic choices, language users continuously weigh up the different principles and strategies to make sure the chosen ones can help to achieve the communicative goals. It is a natural characteristic of language use that there is no one-to-one correspondence between linguistic form and function. Therefore, communication is full of indeterminacies, which are not only a consequence but also a prerequisite of the dynamics of language use.

Since the dynamic negotiation is based upon certain principles, it should be pointed out that the notion of principles is usually put forward as opposed to another concept of rules in the sense that principles are much more flexible than rules. Specifically, rules of language cannot be violated in order to keep the generated sentences well-formed and acceptable, while principles may be either followed or flouted, which would result in different communicative effects or realize distinct communicative goals. It is the functioning of these principles that makes negotiation possible. So far as a political discourse is concerned, there is no such fixed rules that can tell a politician when and why to mix interdiscursive elements. Instead, a politician produces the interdiscursive texts on the basis of flexible principles with the efforts paid to meet the communicative needs.

The choices in the functioning process of a political discourse are made with different degrees of consciousness or awareness. Some choices are highly motivated by the communicative goals while others are made automatically with a lower degree of consciousness.

A political discourse functions as a means of linguistic adaptation. It realizes various pragmatic effects. Communication through the functioning of a political discourse is a dynamic process of mutual recognition/tracing of each other's motivation.

Due to the differences of the motivations and mechanisms behind the functioning of a political discourse, there are diversified kinds of communicative functions associated with this linguistic phenomenon. From the adaptations perspective, a political discourse is not only one of the mirrors reflecting the tendencies of discursive and social development but also one of the tools endowed by language to enable users to satisfy their communicative needs in the short term and to contribute to their survival in the long term as the outcome of successful adaptation.

During this linguistic choice process, the choices are not made mechanically or statically but rather dynamically in a negotiable manner. Based upon this negotiable choice making, a political discourse is produced so as to adapt to variables of the physical world, variables of the social world, and variables of the mental world. Then as a natural consequence of a politician's choice making and adaptation, there come the interdiscursive texts which manifest great variability in terms of element complexity.

The Dadah's electional speech consists of 818 words. The analysis of the frequently used words, phrases and short sentences in his speech was undertaken yielding following results as shown in Table 3: 
Table 3. Keyword frequency percentage (\%)

\begin{tabular}{|c|c|c|c|c|c|c|c|}
\hline No & Keywords & $\%$ & Key phrases & $\%$ & Short sentences & $\%$ & Salience of adaptability \\
\hline 1 & 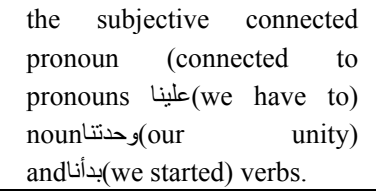 & 3.7 & & & & & $\begin{array}{l}\text { Strength of the notion of unity and } \\
\text { brotherly love. }\end{array}$ \\
\hline 2 & $\begin{array}{l}\text { المواطنون،المواطنات، } \\
\text { male and female citizens }\end{array}$ & 1.5 & & & & & $\begin{array}{l}\text { Strength of the notion of unity and } \\
\text { brotherly love. }\end{array}$ \\
\hline 3 & موريتانيا Mauritania & 0.10 & & & & & Strength of the notion of unity. \\
\hline 4 & & & & & I أدعوكم & 0.6 & $\begin{array}{l}\text { Motivating his voters to elect him } \\
\text { the president of Mauritania. }\end{array}$ \\
\hline 5 & change & 0.4 & & & & & $\begin{array}{l}\text { Appreciation for the positive } \\
\text { attitude of the Mauritanians towards } \\
\text { the change. }\end{array}$ \\
\hline 6 & policy القانون & 0.4 & & & & & $\begin{array}{l}\text { Clarification of his future plan } \\
\text { referring to his government } \\
\text { objectives. }\end{array}$ \\
\hline 7 & democracy الايمقراطية & 0.4 & & & & & $\begin{array}{l}\text { The change of the bad and hard } \\
\text { circumstances of Mauritania to the } \\
\text { democracy of the country based on } \\
\text { religion and morals. }\end{array}$ \\
\hline 8 & تحديتم ,التحدي Challenge & 0.4 & & & & & $\begin{array}{l}\text { Insistence to overcome all } \\
\text { challenges and obstacles. }\end{array}$ \\
\hline 9 & $\begin{array}{l}\text { مشرو عكم، بمشروع ، project } \\
\text { your project، proje }\end{array}$ & 0.4 & & & & & $\begin{array}{l}\text { He appreciates the positive attitude } \\
\text { of the Mauritanians towards the } \\
\text { change and how they fight and } \\
\text { struggle for it. }\end{array}$ \\
\hline 10 & قيادة قLeadership & 0.2 & & & & & $\begin{array}{l}\text { Reference to his government } \\
\text { objectives indirectly to motivate his } \\
\text { voters to elect him the president of } \\
\text { Mauritania. }\end{array}$ \\
\hline 11 & & & $\begin{array}{l}\text { خط أحمر red } \\
\text { line }\end{array}$ & & & 0.2 & $\begin{array}{l}\text { Reference to his government } \\
\text { objectives indirectly to motivate his } \\
\text { voters to elect him the president of } \\
\text { Mauritania. }\end{array}$ \\
\hline 12 & $\begin{array}{l}\text { النضال،المناضلاتو المناضلونStrugg } \\
\text { le,female and male stugglers }\end{array}$ & 0.4 & & & & & $\begin{array}{l}\text { An emphasis of the danger of the } \\
\text { bad political circumstances of } \\
\text { Mauritania to their unity and } \\
\text { stabilization and the necessity of } \\
\text { struggle for change. }\end{array}$ \\
\hline
\end{tabular}

As shown in Table 3, Dadah uses more simple words, phrases and short sentences in order to shorten the distance between him and his voters. He intends to make his audience more easily understand and accept his political speech.

Dadah uses simple present tense to present the domestic situation ranging from political to cultural fields at present. Depending on simple future tense, he refers to his future plans in order to refer to his government's objectives indirectly. He intends to arouse the Mauritania people's confidence toward him and his future government, as in Table 2, No. 15.

The analysis of the ideological aspect of Dadah's electional speech links the discourse with the social processes and decipher covert ideology of his discourse. There is a direct relation between discourse and social 'power', in which 'power' is an abstract concept holding an infinitely important influence on peoples' lives, as in Table 2 , No. 14.

Different types of persuasions in Dadah's speech are used: persuasion through personality and stance in Table 2, No. 22, persuasion through the arousal of emotion, as in Table 2, No. 16 and persuasion through reasoning, Table 2, No. 13. The purpose of using such a strategy is to manipulate the voters into agreeing with policies which really serve only the desire of a politician to gain or keep 'power'. 
In his electional speech, Dadah quotes some verses from the Holy Quran in order to have more influence on people's mind and heart as a means of persuasion, as in Table 3, No. 10.

It is noliceable that less threat is used in Dadah's speech because he intends to show himself as a person who never puts others in bad situations and he wants to show himself as the best person, as in Table 2, No. 17 and 21.

\section{Discussion}

Jef Verschueren has stated that using language is a process of the continuous making of linguistic choices and adaptation. The processes of making linguistic choices have three properties, i.e. variability, negotiability, and adaptability. The adaptability of language is one of the most important properties in language use. It means that the purpose of linguistic choices is to meet the communication needs. The concept of adaptation assigns four angles to the description and explanation of language using: the investigations of the contextual correlates of adaptability, the structural objects of adaptability, the dynamics of adaptability and the salience of the adaptation processes, i.e., the degrees of consciousness in language use. They almost cover all the aspects of a pragmatic analysis of any given language use. In the present study, the four dynamics to which the functioning of Dadah's political advertising discourse gets adapted, are divided into three categories: variables of the physical world, variables of the social world, and variables of the mental world. As a natural consequence of these three different courses of adaptation making, various communicative functions of a political discourse are realized. This research analyzes the ideological components reflected in speech of Dadah to identify the framework of his ideological standpoint. The most significant aspect of this study is the way Dadah makes use of linguistic resources to create positive 'power' in his listeners.

\section{References}

Allen, G. (2000). Intertextuality. London: Routledge.

Baker, P., \& Ellece, S. (n.d.). Key Terms in Discourse Analysis. New York: Continuum Publishing Group.

Beard, A. (2000). The language of politics. Routledge.

Bernstein, B. (2005). Pedagogy, Symbolic Control and identity. London: Taylor \& Francis.

Blommaert, J. (2005). Discourse, a critical introduction. Cambridge University Press. http://dx.doi.org/10.1017/CBO9780511610295

Candlin, C., \& Maley, Y. (1997). Intertextuality and a political discourse in the discourse of alternative dispute resolution. In B. Gunnarsson, P. Linell, \& B. Nordberg (Eds.), The Construction of Professional Discourse (pp. 201-222). New York: Addison Wesley Longman Limited.

Fairclough, N. (1989). Language and power. Longman.

Fairclough, N. (1992a). Discourse and social change. Wiley-Blackwell.

Fairclough, N. (1992b). The appropriacy of appropriateness. In N. Fairclough (Ed.), Critical language awareness (pp. 33-56). Longman.

Fairclough, N. (1995). Critical Discourse Analysis. Boston: Addison Wesley.

Fairclough, N. (2003). Analyzing discourse: Textual analysis for social research. Routledge.

Fowler, R. (1966). On Critical Linguistics. In C. R. Caldas-Coulthard \& M. Coulthard (Eds.), Texts and Practices: Readings in Critical Discourse Analysis (pp. 3-14). London: Routhledge.

Horvath, J. (2009). Critical discourse analysis of Obama's political discourse. Language, Literature and Culture in a Changing Transatlantic World International Conference Proceedings (pp. 22-23). University Library of Prešov University.

Kaid, L. L. (1981). Political advertising. In D. Nimmo \& K. R. Sanders (Eds.), Handbook of political communication (pp. 249-271). Beverly Hills, CA: Sage.

Kaid, L. L. (1994a). Measuring cadidates with semantic differentials. In K. Hackers (Ed.), Candidate images in ptesidential election campaigns (pp. 111-127). New York: Praeger.

Kaid, L. L. (1994b). Political advertising in the 1992 campaign. In R. E. Denton, Jr. (Ed.), The 1992 presidential campaign: A communication perspective (pp. 111-127). Westport, CT: Praeger.

Kaid, L. L. (1999). Political advertising: A summary of research fidings. In B. Newmans (Ed.), The handbook of political marketing (pp. 423-438). Thousand Oaks, CA: Sage Publications. 
Kaid, L. L., \& Boydston, J. (1987). An experimental study of the effectiveness of negative political advertisements. Communication Quarterly, 35, 193-201. http://dx.doi.org/10.1080/01463378709369680

Kaid, L. L., \& Davidson, D. K. (1986). Elements of videostyle: Candidate presentation through television advertising. In L. L. Kaid, D. Nimmo, \& K. R. Sanders (Eds.), New perspectives on political advertising (pp. 184-209). Carbondale: Southern Illinois University Press.

Kaid, L. L., \& Johnston, A. (1991). Negative versus positive television advertising in presidential campaigns, 1960-1988. Journalof Communication, 41, 53-64. http://dx.doi.org/10.1111/j.1460-2466.1991.tb02323.x

Lemke, J. L. (1995). Textual Politics: Discourse and Social Dynamics. London: Taylor \& Fracis.

Scollon, R. (2002). A political discourse and identity. In M. Toolan (Ed.), Critical Discourse Analysis: Critical Concepts in Linguistics (pp. 79-94). London: Routledge.

Van Dijk, A. (1985). Discourse and communication. New approaches to the analysis of mass media discourse and communication. Berlin: de Gruyter. http://dx.doi.org/10.1515/9783110852141

Van Dijk, A. (1995). Discourse analysis as ideology analysis. Retrieved from http://www.discourse.org

Van Dijk, A. (2010). Discourse, power and access. In C. R. Caldas-Coulthard \& M. Coulthard (Eds.), Texts and Practices: Readings in Critical Discourse Analysis (pp. 84-106). London: Routledge.

Verschueren, J. (1987). Pragmatics as a Theory of Linguistic Adaptation. First Working Journal of Cambridge Studies 115 Document Drafted for the International Pragmatics Association in Preparation of a Handbook of Pragmatics. Antwerp: International Pragmatics Association.

Verschueren, J. (1999). Understanding Pragmatics. London: Arnold.

Wang, J. (2010). A Critical Discourse Analysis of Barack Obama's Speeches. Journal of Language Teaching and Research, 1(3), 254-261. http://dx.doi.org/10.4304/j1tr.1.3.254-261

Widdowson, H. G. (1995). Discourse Analysis: a Critical View. Language and Literature, 4, 157-172. http://dx.doi.org/10.1177/096394709500400301

Widdowson, H. G. (1998). The theory and practice of critical discourse analysis. Applied Linguistics, 19(1), 136-151. http://dx.doi.org/10.1093/applin/19.1.136

Wu, J., \& Qin, X. B. (2004). On Bradford's double pattern for stylistic analysis. Journal of Foreign Languages, 153(5), 70-74.

Xin, B. (2000). Intertextuality from a Critical Perspective. Suzhou: Suzhou University Press.

\section{Copyrights}

Copyright for this article is retained by the author(s), with first publication rights granted to the journal.

This is an open-access article distributed under the terms and conditions of the Creative Commons Attribution license (http://creativecommons.org/licenses/by/3.0/). 